\title{
Are Small Farms Sustainable by Nature?-Review of an Ongoing Misunderstanding in Agroecology
}

\author{
Roland Ebel* \\ Department of Health and Human Development, Montana State University, Bozeman, MT, USA \\ * Corresponding author: E-Mail: roland.ebel@gmx.com; Tel.: +1 406994 0211; Fax: +1 4069947360
}

Submitted: 20 September 2019 | In revised form: 9 December 2019 | Accepted: 31 January 2020 | Published: 10 April 2020

\begin{abstract}
Today, agroecology is more than a science; it is a movement that advocates for a sustainable redesign of the global food system. Some of its acknowledged protagonists plead for a redesign based on the support of and for small-scale farming because small farms are considered more sustainable than large farms. The present review explores the arguments that leading agroecologists use for justifying their preference for small (frequently peasant) farms. In this review, small farms are defined as possessing a mean agricultural area of maximum two hectares, being family-owned, emphasizing outdoor production, and annually producing at least two different crops or livestock. Peasant farms are defined as subsistent small farms in developing countries. The review includes an overview of the current state of small farms and their most severe challenges. Agroecological publications of the last thirty years were scanned for arguments that sustain the hypothesis that small farms are more sustainable. It was found that there are no studies that directly compare the sustainability of farms based on their size. Instead, most studies cited to confirm the sustainability of small farms compare farms that differ in terms of both, size and farm management. Hence, it is likely that the reason for the advanced sustainability of small farms is their management, not their size. The assertion that small farms are a priori more sustainable than large ones is not supportable. Misleading use of the term "small farms" may impede the efforts of agroecology to stimulate sustainable food production.
\end{abstract}

Keywords: farm size; peasants; smallholders; sustainable agriculture

\section{Preface of the Author}

"First we need to fragment all big farms because only small farms are sustainable", a student once told me when I asked him how he would increase the sustainability of 1000 ha monocropping farms. Apparently, his answer was at least partially based on what he learned from an agroecology scholar. Most of us dedicated to teaching in the field of sustainable agriculture may have heard or given similar answers. Among agroecology instructors, there is a diffuse idea that the sustainability of a farm is negatively correlated to its size. Certainly, most scholars would give a more detailed and differentiated answer ("not all small farms are necessarily sustainable") and would come up with some remarks to the "fragment all big farms" solution, but what eventually resonates among the students and the broader audience is "small is more sustainable".

"Is this romanticism or based on facts?", I asked myself and started reading publications in this regard. This effort soon evolved into a systematic review of the sustainability of small 
farms, which I am glad to share now with a broader audience. The essence of my study is that yes, small farms are more sustainable - but this depends on everything but their size. Before justifying this statement, I would like to highlight two considerations: (1) Peasant farms are a particular segment of small farms. The review distinguishes between concepts that apply for all small farms and those which only apply for peasant farms. Having lived for years in a peasant farming community, I question everything but the sustainability of peasant farms and consider them the most important source of inspiration for sustainable farming. (2) The present article does not suggest consequences for agroecology as science or as a movement; it only discusses and questions the small is unconditionally better dogma [1-5]. It cannot be ruled out that eventually, the student's answer was the correct one.

\section{Introduction}

Agroecology is a scientific discipline, an agricultural practice, as well as a political and social movement [6]. Especially in its function as a movement, it calls for the redesign of the global food system; and following acknowledged agroecologists, this redesign should be based on the support of and for small-scale farming $[7,8]$. The tight relationship of agroecology with small farms and farmers is no coincidence since most of the practices the discipline recommends are primarily based on small farmers' traditional knowledge and management practices, which existed long before the concept of agroecology was developed [9].

Apart from this historic connection, the present review explores the arguments that numerous agroecologists use for justifying their preference for small (frequently peasant) farms. It starts with a definition of the terms small farm, small farmer and peasant farmer. This clarification is necessary because the use of these terms in agroecological (and other) publications is imprecise [10]. To highlight today's persisting significance of small farms to global agriculture and food systems, the subsequent chapters deal with their current situation and challenges. Then, the review provides proof of the preference of leading authors in the field of agroecology for small farms.

The next chapters include the core findings of the review. Agroecological publications of the last thirty years were scanned for arguments that sustain the hypothesis that small farms are (environmentally and socially) more sustainable than large farms. Most notably, quantitative studies that directly compare the sustainability of farms based on their size were not found. However, the present review discusses studies where small and large farms were compared based on other parameters. Then, reported arguments for the advanced sustainability of small farms are listed. To complete the picture, the following chapter highlights sustainability disadvantages of small farms evidenced in the reviewed publications. In the discussion, the claimed sustainability advantages of small farms are contrasted with their relation to actual farm size.

\section{Methods}

The present article is based on a comprehensive critical review of agroecology literature addressing the review question of whether (and why) small farms are more sustainable than large farms. The review was conducted in three steps:

In the first step, potentially suitable articles were identified, and their abstracts were reviewed. Therefore, only academic papers written in English that addressed the review question directly in the title or abstract were considered. This process covered peer-review articles of the period 1990-2019. All possible combinations of the terms "small farm(er)" or "smallholder", "agroecology", and "sustainable" or "sustainability" were searched. Electronic databases consulted include Web of Science, ScienceDirect, and ProQuest. Subsequently, data was extracted from 44 full texts.

Secondly, reference lists of all articles identified in the first step were screened in order to find additional publications that address the review question. Since numerous references included publications in Spanish, this language was also considered. Apart from research articles, essays, well-written practitioner publications, as well as strategy and opinion papers were now also permitted. Step two was conducted through a manual search, and data was extracted from additional 29 full texts.

Thirdly, specific procedures were established for developing Table 1 (studies cited to sustain the advanced sustainability of small farms.), Table 2 (reported sustainability advantages of small farms), and table 3 (justification of sustainability benefits of small farms). For the development of Table 1, the two most cited publications (following Google Scholar) resulting from the search term combination "small farm", "agroecology", and "sustainability" were identified. Then, all studies cited in these papers to prove the sustainability of small farms were reviewed and analysed. As for table 2, a thematic analysis [11] was applied for all articles identified during review steps one and two. Consequently, the listed arguments for the claimed sustainability of small farms were analysed based on ten themes. Similarly, in table 3, the same publications were analysed along 22 themes, which were grouped into three categories: farmlevel, personal and economic level, as well as community level.

Finally, since these chapters require data that goes beyond the current discussion in agroecology, for the chapters "Definition of a small farm" and "Small farms in numbers", further information was searched manually.

\section{How Small is Small?-Definition of a Small Farm}

Frequently, the farm size is used to classify farms [12], but the use of the term small farm lacks clarity [10]. Commonly, size refers to the area of land owned by a farm operation, but it can also be limited to the farmed area, the mean agricultural area. Herrero et al. [13] provide an example of an area-based classification scale: very small farms own less than 0.5 ha, small farms $(0.5-2$ ha), medium farms $>2-100$ 
ha, and large farms $>100$ ha. A maximum property of 2 ha is a common threshold for the distinction between small and larger farms [10,14-16]. Seldom, 5 ha is the critical value $[2,17]$. A second definition of small farms refers to farm ownership. Accordingly, small farms are family-operated (sometimes including more than one household) with limited or no hired labour $[10,14,17,18]$. In high-income countries, the generated value is also a common indicator: for example, the USDA defines small farms as farms with less than $\$ 100,000$ in value of annual production and distinguishes them from "non-commercial" farms which make less than $\$ 50,000$ per year [19]. In terms of farm management, small farms are characterized as being diversified [12] although this indicator is not sustained by a clear number. Finally, most small farmers are dedicated to food production and under-represented in export and agrofuel production [20].

The term family farm is a common synonym for small farm $[4,10,12,15,17,19,21-24]$, although it can also exclusively refer to the farm ownership (which then includes family-run larger-scale farms). The operator of a small farm is called a small farmern [4,20,25-27], smallholder $[2,10,12-14,21,28]$, or family farmer [14]. Peasant (or peasant farmer) commonly refers to the same group of farm owners but emphasizes subsistent (often indigenous) producers in developing countries $[2,4,17,22,28,29]$, characterized by a strong relationship with the local culture and environment, an empiric rather than academic knowledge about farm management, and little use of external inputs [1].

In the present review, small farms are defined as a) possessing a mean agricultural area of maximum 2 ha, b) being family-owned, c) emphasizing outdoor production (to demark from greenhouses and other types of intensively controlled environments), and d) annually producing at least two different crops or livestock. Peasant farms are defined as subsistent (more than $50 \%$ of the production is designated to family consumption) small farms in developing countries.

\section{Small Farms in Numbers}

Providing exact numbers about the actual state of small farms and their role in the global food system is challenging. The available data is limited and unprecise due to inconsistent computation in different countries. Additionally, most data is based on household surveys that do not include non-family-owned large farms [10].

The widely reported claim that smallholders in developing countries produce up to $80 \%$ of the world's food is probably not supportable [21]; this number is only proven for Asia and sub-Saharan Africa [30]. A small farm contribution to global nutrition of $50 \%$ [19] to $60 \%$ [27] seems to be a realistic estimation.

There is a relatively broad consensus that there are approximately 570 million farms worldwide, of which, at least 500 million (88\% of total farms) are family farms $[10,14,30]$. Other sources report that up to $98 \%$ of all farms are familyowned [21]. Of all farms worldwide, $83 \%$ are considered small farms in developing countries, where they provide $60 \%$ of the total rural income $[12,26]$.

Of the three billion rural people in the developing world [12], over two-thirds are estimated to live on small farms [31]. Consequently, the current global population of small farmers is estimated at 2.0-2.5 billion [30,32]. Independent from size, $74 \%$ of all farms stand in East and South Asia and the Pacific (China alone represents $35 \%$ of all global farms), $9 \%$ in Sub-Saharan Africa, $7 \%$ in Europe and Central Asia, 4\% in Latin America and the Caribbean, 3\% in the Middle East and North Africa; and the rest in non-European high-income countries [10].

There is conflicting information about the area of land managed by small farmers. 53\% of all agricultural land is managed by family farmers (without contemplating the maximum farm size) [14]. Lowder et al. [10] state that farms less than 2 ha (most of them owning less than 1 ha) operate about $84 \%$ of the world's agricultural land. Accordingly, since 1960, the average farm size has decreased in the developing world and increased in the developed world, making the farmland distribution more unequal in high-income countries than in developing regions. In the richest countries, farms larger than 20 ha operate $70 \%$ of the land, while in the poorest countries, $70 \%$ of the land is operated by farms smaller than 5 ha [33].

Small farms ( $<2$ ha) have the most relevance in SubSaharan Africa, Southeast Asia, and South Asia, where they contribute to about $30 \%$ of most food commodities [13]. The average size of a smallholder farm in Bangladesh is only 0.24 ha. Outstanding countries are also Kenya and Tanzania, where small farmers produce 63 and 69 per cent of the food, as well as Bolivia with a supply of $85 \%$ of the country's food consumption through small farm [12]. Remarkably, in the European Union, $50 \%$ of all farms are small farms but operate only $2 \%$ of the agricultural land [10]. Globally, there is a trend that the smaller the property, the more labour per unit area is applied [31].

In terms of management, most small farms in Asia are irrigated, while African and Latin American smallholder agriculture is widely rainfed [12]. The diversity of agricultural production diminishes as farm size increases [13]: Farms under 2 ha account for a clearly higher agrobiodiversity than their larger counterparts [21]. The majority of globally consumed micronutrients and protein are produced in such diverse farms, while the majority of sugar and oil crops come from less diverse ones. Notably, farms smaller than 20 ha provide $71 \%$ of global vitamin A production [13]. However, only $18 \%$ of globally consumed food calories come from small farms [21]. Also, only $4 \%$ of smallholder production is wasted, compared to farms bigger than 1000 ha which waste around $7.5 \%$ [21].

\section{Current Challenges of Small Farms}

Small farms are facing numerous challenges today. It is not the purpose of this review to highlight all of them or to discuss them in-depth. Thus, the following chapter is 
limited to challenges that are affecting the survival of small farms and their sustainability advantages compared to large farms. Most of these challenges apply prevailingly for peasant farms.

Climate change affects all farmers, of all sizes and provenances. Yet, regardless of the functional resilience of diverse small farms to climatic alterations [34], small farmers are highly vulnerable to the negative impacts of climate change such as natural disasters, drought, high temperatures, elevated pest and pathogen pressure, and altered nutrient uptake [35]. This susceptibility is caused by their frequent location in marginal areas and a lack of access to technical or financial support. Furthermore, peasant farms in many regions of the world strongly depend on rainfed agriculture [36,37]. As climate change causes shifts in precipitation, the challenges with rainfed agriculture are increasing.

The major concern for many small farmers, however, is access to fertile land. Land availability for small-scale farmers has drastically decreased due to large-scale land acquisitions by transnational companies or large national farm enterprises, political conflicts over land tenure, urban growth, political conflicts up to wars [36], failed rural development politics, and environmental problems such as drought as a consequence of climate change [37]. Additionally, high productivity levels of large farms (per area, not per input) decrease the competitiveness of small farms on an estate market with globally increasing costs of land [23]. Small farmers, consequently, either struggle economically, move to marginalized areas, try to expand, or abandon farming (resulting in a rural exodus in most parts of the world). This process occurs more aggressively in developing countries but the loss of small farms (e.g., through bankruptcy) is stronger in developed nations [38,39].

In developing countries, the concern of peasant farmers for fertile land is followed by worries about limited access to other essential resources such as water. These resources are increasingly being taken away from the majority of peasants (prevailingly producing for the domestic food supply) and utilized in a small segment of farms engaged in export production [2].

A weak economic position of peasant farms also decreases their market and access to services, as well as policy support [2] and most of today's research does not meet the needs and priorities of peasants [1]. Furthermore, globalization has caused downward price pressures and costly regulatory burdens for small farmers in both developed and developing countries [27]. Equity and sustainability standars for peasant farmers awarded by multinationals and international NGOs (e.g. "Fair trade") intend to increase the economic sustainability of these farms by giving them a higher share of the profits in the global food market. However, recent research shows that, for example, in coffee production, the economic gain for small farmers from certified products is relatively low [40].

Another problem of small-scale farmers relates to a constant need to gain money (even if they produce their own food), to cover for transport, health, and education expenses. Consequently, small farmers now rely on an increasingly diversified mix of non-farm and off-farm livelihood activities, especially migration [41]. The result is an ongoing rural exodus and an ageing peasant population. These tendencies do not only affect the farms' management (which is labour demanding) but also off-farm ecosystem services provided by small-scale farming. In Mexico, the abandonment of traditional farming techniques (impossible to maintain in the absence of abundant family labour) increases the cost of resource conservation [29]. Rural exodus and ageing farmers also jeopardize the survival of traditional lifestyles of small producers. These traditions are sometimes even a trigger for migration as many young people in rural areas relate them to poverty and underdevelopment $[3,42]$. Rural exodus does not only occur in the developing world but is observed in developed countries in Europe [38] and North America as well [39].

\section{Agroecology and Small Farms}

A scientific discussion about the sustainability of farming of any size cannot ignore agroecology. Following Amekawa [43], it is the most effective facilitator of the concept of sustainable agriculture and remains the least compromised critic of modern industrial agriculture [43]. Agroecology originally emphasized crop production and protection, but dimensions such as environmental, social, economic, ethical and development issues are becoming more relevant. Today, the term applies for three levels: 1) agroecology as a scientific discipline, 2) as an agricultural practice, or 3) as a political social movement [6].

The "sustainability of small farms" discussion occurs at all levels but is most present at the "agroecology as a movement" level where the primary concepts of agroecology resonate with arguments for food security, food sovereignty and sustainable rural development $[8,44]$. Accordingly, the present understanding of agroecology as a social movement (especially, but not exclusively, for peasant farmers) provides a productive basis for rural movements that promote food sovereignty [4]. Giraldo and Rosset [3] even consider agroecology a social relationship distinct from capitalism. In the debate about the advanced sustainability of small, particularly peasant, farms there are differentiated voices such as Frison [27] who is against limiting agroecology to small-scale farming but instead calls it a universal logic for redesigning agricultural systems as part of a holistic strategy to build fertile and healthy agroecosystems and secure livelihoods. Yet, there are also numerous agroecology scholars and activists who clearly make the point that agroecology is a science dedicated to the interests of small farmers as the primary focus of development [43] and justify this with their advanced sustainability:

- Agroecological systems are deeply rooted in the ecological rationale of traditional small-scale agriculture [4]. 
- Agroecology initially focuses on small-scale farmers [5].

- Agroecology as science is foremost based on the rediscovery and study of traditional peasant agriculture [45].

- Agroecology perceives small-scale farmers, particularly those living in environmentally risk-prone areas, as the actor category of primary importance [43].

- Agroecology and food sovereignty advocates share a concern for the conservation of indigenous knowledge, the right of consumers to sufficient and healthy food, and the right of food producers to a livelihood [44].

- The roots of agroecology lie in the ecological rationale of indigenous and peasant agriculture still prevalent in many parts of the developing world. There is an inverse relationship between farm size and output [24].

- Land productivity of the most traditional peasant agricultures can be strongly increased through agroecology. Agroecology appears as a key strategy of re-peasantization $[1]$.

- Agroecology contributes towards the process of "repeasantization" in which, contrary to the general tendency of migration from the countryside to the city, smallholders are returning to the land. If de-politicized, the term agroecology is rendered meaningless, divorced from the realities of smallholders and family farmers, and politically powerless [2].

- Agroecology is one key element of broader societal transformations that challenge capitalism, colonialism, standardization, industrialization, patriarchy, and other forms of injustice [22].

\section{Why Small Farms are Considered More Sustainable}

The central question of this review, why small farms are considered more sustainable than larger ones, is divided into two parts. Only a few publications refer to (experimental or case) studies that reportedly compare small and large farms. The most outstanding proofs are listed in the subchapter "Cited studies". Most publications that advocate for the sustainability of small farms do not provide evidence for this claim. Their argumentation is resumed in the subchapter "Sustainability claims which are not based on studies".

\subsection{Cited Studies}

Table 1 provides a listing of all field empiric studies cited in outstanding agroecology publications $[24,46]$ as evidence to prove the sustainability of small farms. It highlights a total of seven case studies and trials, where farm systems of different size were compared, and includes information about the differences between the studied systems. Noteworthily, only three out of seven studies deal with farming systems of different sizes, and even these studies are about farms or fields with varying management so that a direct comparison is not possible. In these studies, most of the benefits attributed to the farms' smallness (higher yield and organic matter productivity per area, higher energy efficiency, healthier soils, and resilience to climatic perturbances) are actually related to an advanced agrobiodiversity of the smaller farms.

\section{Sustainability Claims Which Are Not Based on Studies}

The second part of the review deals with influencing, groundbreaking and frequently cited agroecology essays, reviews, research articles, or opinion papers that agitate for the sustainability of small and peasant farms without providing field data. In these publications, the arguments in favour of advanced sustainability of small farms can be divided into sustainability advantages that apply for all small farms and those that only apply for peasant farms (Table 2). Some publications also state explicit disadvantages of small farms which are highlighted subsequently. It must be considered that the discussed characteristics of small farms are limited to the agriculture of our days. Historically, especially at the early stages of capitalism, the economic sustainability of independent small farm enterprises was higher than the ponderous big-scaled farm operations of the feudal system. This explains, for example, the competitive advantage of the early United States (US) against the former colonies in Latin America with their hacienda system [20].

\subsection{Arguments (According to Authors) for Sustainability Advantages of Small Peasant and Non-peasant Farms}

Small farms are less dependent on commercial inputs than large farms [34]. They utilize a broad array of resources like manure and compost produced on-farm or regionally [45]. This reduces their expenses for commercial products. The diversity of inputs also decreases their susceptibility to resource shortages $[1,31,47]$ and stimulates the agrobiodiversity of their farming systems regarding both crop/livestock and associated (for example, soil microflora) species [48]. Furthermore, diversified farm inputs mean diverse management strategies and cropping systems [45], which increase the farm system stability [49]. Small farms usually use less mechanized equipment than large farms and, therefore, consume less fossil fuel [44], which increases their economic and environmental sustainability. The reasons for the moderate use of external inputs in small farms are strongly related to low spending power of most of these operations. Yet, a functional understanding of agroecological processes (as a consequence of traditional ecological observation due to age-long collective agroecosystem observation), as well as an intact knowledge about traditional farming practices, also play an essential role for the lower demand for external 
inputs [8,24]. Furthermore, not only do small farms use less external resources than large farms, the use of internal (including land and water) and external resources is also more efficient [24,31,50,51]. Also, small farms provide numerous valuable ecosystem services to the larger society [20] as they generate a diversity of landscapes and stimulate biodiversity as well as ecosystem stability in their surroundings. This is caused by a broad mixture of implemented cropping systems, high agrobiodiversity, adaptation to the local environment, and low input-dependence [45,52].

Table 1. Selection of studies cited in benchmark publications in agroecology to sustain the advanced sustainability of small farms.

\begin{tabular}{|c|c|c|c|c|c|}
\hline Study title, reference & $\begin{array}{l}\text { Citation as } \\
\text { proof of } \\
\text { advanced } \\
\text { sustainability } \\
\text { of small farms }\end{array}$ & $\begin{array}{l}\text { Compared farming } \\
\text { systems }\end{array}$ & $\begin{array}{l}\text { Difference between } \\
\text { compared farming } \\
\text { systems }\end{array}$ & $\begin{array}{l}\text { Size difference } \\
\text { between } \\
\text { compared } \\
\text { farming systems }\end{array}$ & Outstanding results \\
\hline $\begin{array}{l}\text { Comportamiento de tres } \\
\text { especies (maíz, frijol, } \\
\text { calabaza) en policultivos } \\
\text { en la Chontalpa, Tabasco, } \\
\text { México [53] in [54], also } \\
\text { cited as [55] }\end{array}$ & {$[46]$} & $\begin{array}{l}\text { Maize-squash-bean } \\
\text { polyculture versus the } \\
\text { same crops in } \\
\text { monocropping } \\
\text { arrangement }\end{array}$ & $\begin{array}{l}\text { Cropping system } \\
\text { arrangement }\end{array}$ & Not specified & $\begin{array}{l}\text { Polycropping generates more } \\
\text { dry matter for incorporation in } \\
\text { soil and results in higher land } \\
\text { equivalent ratio (LER) }\end{array}$ \\
\hline $\begin{array}{l}\text { Farm size and productivity } \\
\text { in Malawian smallholder } \\
\text { agriculture [56] }\end{array}$ & {$[46]$} & $\begin{array}{l}\text { Interpretation of national } \\
\text { farm survey from Malawi } \\
\text { in the early } 1980 \text { s }\end{array}$ & $\begin{array}{l}\text { Farm management } \\
\text { (especially } \\
\text { fertilization), farm size, } \\
\text { agrobiodiversity }\end{array}$ & $\begin{array}{l}\text { Increasing farm } \\
\text { size means lower } \\
\text { proportion of land } \\
\text { under staple crops } \\
\text { (trend) }\end{array}$ & $\begin{array}{l}\text { Positive relationship between } \\
\text { farm size and productivity and } \\
\text { net returns respectively }\end{array}$ \\
\hline $\begin{array}{l}\text { Agro-Ecological Indicators } \\
\text { (AEls) for Dairy and Mixed } \\
\text { Farming Systems: } \\
\text { Identifying Alternatives for } \\
\text { the Cuban Livestock } \\
\text { Sector [57] }\end{array}$ & {$[46]$} & $\begin{array}{l}\text { (Two types of) mixed } \\
\text { (crop-livestock) versus } \\
\text { dairy farming systems } \\
(n=93)\end{array}$ & $\begin{array}{l}\text { Farm management, } \\
\text { farm size, years since } \\
\text { conversion to mixed } \\
\text { farming }\end{array}$ & $\begin{array}{l}\text { Most small farms: } \\
\text { mixed farming; } \\
\text { most large farms: } \\
\text { dairy systems }\end{array}$ & $\begin{array}{l}\text { Small farms (when they had } \\
\text { higher plant than animal } \\
\text { portions) showed significantly } \\
\text { higher milk yields per forage } \\
\text { area and increased energy } \\
\text { efficiency }\end{array}$ \\
\hline $\begin{array}{l}\text { Evaluación inicial de } \\
\text { sistemas integrados para } \\
\text { la producción de alimentos } \\
\text { y energía en Cuba [58] }\end{array}$ & {$[46]$} & $\begin{array}{l}\text { Selected farming systems } \\
\text { in three Cuban provinces } \\
\text { varying in size and } \\
\text { management classified in } \\
\text { three categories of } \\
\text { food-energy- integration } \\
(n=25)\end{array}$ & $\begin{array}{l}\text { Agrobiodiversity, farm } \\
\text { management } \\
\text { (food-energy- } \\
\text { integration), size }\end{array}$ & $\begin{array}{l}\text { Farms }<15 \text { ha } \\
\text { (different } \\
\text { management } \\
\text { approaches, } \\
\text { frequently } \\
\text { traditional } \\
\text { management) } \\
\text { versus farms }>15 \\
\text { ha }\end{array}$ & $\begin{array}{l}\text { Smaller farms showed higher } \\
\text { agrobiodiversity, energy } \\
\text { efficiency and productivity by } \\
\text { trend. The higher the } \\
\text { food-energy-integration, the } \\
\text { higher the productivity per area, } \\
\text { the energy efficiency, the } \\
\text { protein and energy supply, and } \\
\text { the DPE (an index that } \\
\text { considers diversity, productivity } \\
\text { and efficiency) }\end{array}$ \\
\hline $\begin{array}{l}\text { Measuring farmers' } \\
\text { agroecological resistance } \\
\text { after Hurricane Mitch in } \\
\text { Nicaragua: a case study in } \\
\text { participatory, sustainable } \\
\text { land management impact } \\
\text { monitoring [59] }\end{array}$ & [24] & $\begin{array}{l}\text { Plots of } 0.5-1.5 \text { ha with } \\
\text { conventional or } \\
\text { agroecological } \\
\text { management, assessed } \\
\text { as pairs of farms with } \\
\text { topographical similarity } \\
\text { and proximity }(n=880)\end{array}$ & $\begin{array}{l}\text { Cropping system } \\
\text { arrangement }\end{array}$ & $\begin{array}{l}\text { None (study is } \\
\text { based on individual } \\
\text { plots of different } \\
\text { farms) }\end{array}$ & $\begin{array}{l}\text { After the landfall of hurricane } \\
\text { Mitch, agroecological plots } \\
\text { showed more topsoil, higher } \\
\text { field moisture, less erosion risk, } \\
\text { and lower economic losses than } \\
\text { conventional farms; differences } \\
\text { increased by trend with higher } \\
\text { storm intensity, increasing } \\
\text { slope, and years under } \\
\text { agroecological management. }\end{array}$ \\
\hline $\begin{array}{l}\text { Agroforestry management } \\
\text { as an adaptive strategy } \\
\text { against potential } \\
\text { microclimate extremes in } \\
\text { coffee agriculture [60] }\end{array}$ & [24] & $\begin{array}{l}\text { Coffee farms, mainly } \\
\text { differing in terms of shade } \\
\text { provided by trees }(n=3)\end{array}$ & $\begin{array}{l}\text { Different shading of } \\
\text { coffee plants due to } \\
\text { varying integration } \\
\text { into agroforestal } \\
\text { systems and coffee } \\
\text { variety }\end{array}$ & Not specified & $\begin{array}{l}\text { High shading causes } \\
\text { significantly smaller fluctuations } \\
\text { in temperature, humidity, solar } \\
\text { radiation, and soil moisture }\end{array}$ \\
\hline $\begin{array}{l}\text { The effects of water stress } \\
\text { on yield advantages of } \\
\text { intercropping systems [61] }\end{array}$ & [24] & $\begin{array}{l}\text { Six different experimental } \\
\text { cropping systems with } \\
\text { sorghum, millet and } \\
\text { varying densities of } \\
\text { intercropped peanuts, } \\
\text { exposed to different soil } \\
\text { moisture regimes }\end{array}$ & $\begin{array}{l}\text { Cropping system } \\
\text { arrangement }\end{array}$ & None & $\begin{array}{l}\text { Higher dry matter yield in } \\
\text { intercropping systems }\end{array}$ \\
\hline
\end{tabular}


Table 2. Claims of sustainability advantages of small farms (compared to large farms) in publications in the field of agroecology, split into advantages that apply for all farms and only for peasant farms.

\begin{tabular}{|c|c|c|c|}
\hline Sustainability advantage & All small farms & Only peasant farms & References \\
\hline \multicolumn{4}{|c|}{ Self-sufficiency } \\
\hline Use of local and diverse resources & $x$ & & {$[24,45]$} \\
\hline Efficient resource use & & $x$ & [24] \\
\hline Low dependence on external (off-farm) inputs & $x$ & & {$[34,45]$} \\
\hline \multicolumn{4}{|c|}{ Crop management } \\
\hline In-situ conservation of local varieties and landraces & & $x$ & {$[1,24,62]$} \\
\hline Diversity of cropping systems & $x$ & & {$[45]$} \\
\hline \multicolumn{4}{|c|}{ Farm system output } \\
\hline Supply of stable yields & & $x$ & [24] \\
\hline Elevated productivity per plant & & $x$ & {$[20,24]$} \\
\hline \multicolumn{4}{|c|}{ Landscape diversity and environmental benefits } \\
\hline Ecosystem services to surrounding areas & $x$ & & {$[20]$} \\
\hline Diversity of landscapes & $x$ & & [45] \\
\hline Low use of fossil fuels & $x$ & & {$[44]$} \\
\hline \multicolumn{4}{|c|}{ Agroecosystem resilience and adaptation to climate change } \\
\hline $\begin{array}{l}\text { Adaptation to changing environmental conditions and minimization of } \\
\text { risk of harvest loss }\end{array}$ & & $x$ & {$[8,24,34,48,62,63]$} \\
\hline Adaptation to the local environment & & $x$ & {$[4,8,20,34,45,48]$} \\
\hline \multicolumn{4}{|c|}{ Nutrition } \\
\hline Provision with diverse and healthy food & $x$ & & {$[24,43]$} \\
\hline \multicolumn{4}{|c|}{ Farmer's attitude and socio-political environment } \\
\hline High sense of responsibility, purpose and control & $x$ & & {$[45]$} \\
\hline Interest in resource and material sustainability & $x$ & & {$[45]$} \\
\hline Farmer empowerment & & $x$ & [43] \\
\hline \multicolumn{4}{|c|}{ Socio-cultural aspects } \\
\hline Maintenance of local culture and traditions & $x$ & & {$[24,45]$} \\
\hline Maintenance of social fabric & $x$ & & [23] \\
\hline \multicolumn{4}{|c|}{ Socio-economic aspects (farm-level) } \\
\hline Low dependence on multinational corporations & & $x$ & [64] \\
\hline Identification of supply niches & & $x$ & [43] \\
\hline Diversification of farm-income & & $x$ & {$[31,43]$} \\
\hline \multicolumn{4}{|c|}{ Socio-economic aspects (local and national level) } \\
\hline Prevention of migration to urban areas & $x$ & & {$[45]$} \\
\hline Support of rural employment & $x$ & & {$[1,23,31,44,45]$} \\
\hline Prevention of migration to urban areas & $x$ & & {$[45,65]$} \\
\hline
\end{tabular}

The elevated efficiency of small farms is commonly attributed to a greater sense of personal responsibility of the single farmer who, accordingly, is naturally interested in resource and material sustainability [45].

The role of small farms as conservationists of rural (frequently indigenous) cultures should not be underestimated. In developing and developed countries, diverse cultural traditions are closely connected to agricultural activities, which are prevailingly cultivated by small farmers. Especially peasants use this traditional ecological knowledge, embedded in their cultural and religious traditions and their food, to increase the sustainability of their farming systems $[45,66]$. Not only due to their key role in conserving traditions and knowledge, small farms play an important role in maintaining the social fabric of rural areas [23,67]. Small farms often apply more labour per unit area, supporting rural employment and, therefore, decreasing migration to urban areas $[23,44,45]$. They also rely more strongly on local businesses and services than large farms [45]. For the US, it was found that in farming communities dominated by large corporate farms, nearby towns died off, while in towns surrounded by smaller farms, the income circulated 
among local business establishments, generating jobs and prosperity [65].

\subsection{Arguments (According to Authors) for Exclusive Sustainability Advantages of Peasant Farms}

Peasant agriculture frequently goes beyond a low use of external inputs as in non-peasant small farms. Occasionally, peasant farms demand as little as zero off-farm resources [62] or rely exclusively on local resources [24]. This makes them independent from products of multinational corporations and empowers peasants to defend (and expand) their role in the food system $[43,64]$.

A second asset that applies more to peasant than to other small farms is their role in the in-situ conservation of crop genetic resources (local crops, breeds, and varieties) $[24,62]$. Due to the intergenerational selection of phenotypes with traits adapted to local environmental conditions and the demands of traditional cuisines, peasants are acknowledged as agrobiodiversity conservationists of agricultural and non-crop species $[1,68]$. For subsistence farmers, diversity in the field also means diversity on the table $[24,43]$. Due to the integration of diverse and well-adapted crop and animal species, most peasant farms count with a built-in resilience to changing environmental conditions $[24,52,62]$. A functioning integration into the local ecosystems, the use of multiple, complex cropping strategies, the high resource efficiency, and the knowledge about traditional farming management, foster the resilience of peasant farms to external alterations, particularly climate change [20,24,45,52,69]. Agrobiodiversity, especially polycropping, which characterizes almost all traditional farming systems, also guarantees stable yields over the long term. It is proven that well-done polycropping provides a higher productivity per plant than monocropping [20,24,52].

Finally, peasant farming is characterized by low mechanization and labour-intensive traditional farming practices. Therefore, it generates even more employment than other types of smallholder agriculture. The low degree of mechanization also decreases the overall carbon footprint od smaller farms $[1,31,43,45]$.

\subsection{Arguments (According to Authors) for Sustainability Disadvantages of All Small Farms}

Certain highly biodiverse smallholder practices (more common in developing countries) are characterized by a high per-area share of non-crop species. Despite the usually beneficial interactions between crops and non-crops, this reduces the area designated to the production of edible species [44]. In production systems such as agroforestry, inefficient farm system design or wrong crop management choices can increase competition for light, nutrients, and water (for example between annual crops and trees), and therefore endanger the food security of a smallholder family [70].

In economic terms, small farmers are disadvantaged since they cannot obtain credit and inputs on the same terms as larger operators [31]. Yet, the demand for money is increasing. Due to little mechanization because of low spending power for equipment and fewer opportunities for mechanization (for example, harvesters for most polycropping arrangements have not been developed yet), small farms require more labour per area than large farms. This is an advantage as it creates employment opportunities but also challenges the smallholders' budgets, especially since less and less family labour is available and many farms have to employ farm workers for harvest and other labourintense activities $[35,44]$. If they want to commercialize their products, small farms often struggle with difficult market access, restrictive regulations, high food safety and quality standards, and the other trade requirements $[50,71]$. The size and remoteness of some small farms can also increase costs for storage, processing, and transport [44], especially if they do not opt for collective processing and sale.

\section{Discussion}

The assumed superior sustainability of small farms is not well constituted. First, most publications that make this claim do not provide a clear definition of what exactly they understand by sustainability. While there is large agreement on what sustainable farm design and management mean, even about socio-economic and socio-cultural aspects at the individual farm or farming community level (agroecosystem level), there is less precise reference to sustainability at the food and social-ecological systems level; and a universal definition of sustainability is almost never provided -probably because the authors assume that there is a consentient understanding of sustainability among agroecologists, which is certainly not guaranteed.

At the agroecosystem level, numerous authors refer to sustainability definitions as expressed in Pretty [72], which incorporate the concepts of resilience (the capacity of systems to buffer shocks and stresses) and persistence (the capacity of systems to continue over long periods), and also consider wider economic, social and environmental outcomes. Regarding sustainable farm management, the definition of Gliessman [73] and similar approaches, which emphasize parameters such as nutrient recycling, energy flow, self-regulation, soil quality, or agrobiodiversity, are vast consensus. Corresponding indicator-based assessment tools for the farm level include the IDEA [74] or the MESMIS [25] framework. Only occasionally, the sustainability of farms is discussed in the context of social-ecological systems (SES), which describe complex, integrated, adaptive systems, delimited by spatial or functional boundaries, in which humans, thus farmers in a specific food system, are seen as components of nature [75,76]. Stronger use of the concept of SES would be convenient for the debate about assessing the sustainability of farms in relation to their size as it helps overcome disciplinary boundaries and consider all dimensions of sustainability. Finally, a contemporary and appropriate universal definition of sustainability that could enhance the debate about small farms is the 
five-dimensions-of-sustainability concept [77].

Second, apart from an indistinct definition of sustainability and how it can be assessed, the supposed sustainability advantages of small over large farms are not supported by robust, valid, and reliable data. Table 1 includes experiments and case studies that are commonly cited to confirm the sustainability of small farms by comparing them to large farms $[24,46]$. These studies involve farms that occasionally differ in terms of size but always differ in terms of farm management (use or non-use of pesticides, use of commercial seeds versus landraces, or high or low agrobiodiversity), which makes them invalid sources of information. Only comparisons of differently sized farms but with equal management would be a solid basis to assess whether there is an a priori sustainability benefit of small farms. Such studies were not identified in the reviewed literature. However, experimental settings, where the impact of farm size on farm sustainability could be assessed validly, would not be difficult to develop. Thus, the question is whether someone seriously questions that, for example, nutrient recycling depends on farm management and not on farm size. Real data comparing existing large and small farms with similar management would be harder to obtain, as we all know that most large farms are not operated the way a peasant farm is managed.

As for agroecology publications that advocate for small farming without providing field data, Table 3 re-examines the most frequently mentioned sustainability benefits of small farms (highlighted in Table 2) and explores the explanations given for these benefits. It also presents arguments that relate these benefits to both farm size and management.

For most benefits, there are no arguments that explicitly relate sustainability and farm size. In some cases, an indirect relationship may be assumed. This applies to arguments that explain the advanced sustainability of small farms by lower use of synthetic and other off-farm products due to the low spending power of small farms. Only two arguments refer directly to the farm size: (1) a lower per area fuel consumption of small compared to large farms and (2) several relatively unprecise statements that relate the enhanced sustainability of small farms to the attitude of their operators.

Outside the agroecology cosmos, there are scholars that (to a certain degree) positively relate farm size and sus- tainability as they demand farms large enough to make use of the necessary mechanization as long as agrobiodiversity is guaranteed [78].

\section{Conclusions}

The present review discloses that the widespread assertion in agroecology literature that small farms are a priori sustainable is not supportable. Studies that allegedly prove the sustainability of small farms compare their management, not their size. Table 1 highlights that all studies mentioned in benchmark publications that claim sustainability benefits of small farms [24,46] do not provide substantial proof of the impact of the scale of an operation on its sustainability. Second, in many publications, the elevated sustainability of small farms is not even evidenced. In these papers, the authors make the case for the (sustainable) way most small farms are operated. Yet, the possibility that the same management would equally enhance the sustainability of larger farms is not discarded.

In conclusion, there is evidence that small farms are more sustainable than large farms, but this depends on diverse management strategies (e.g., high agrobiodiversity or use of landraces), which are more frequently applied in small farms, not directly on their size. Only two clear size-related arguments were identified: first, small farms use less fuel per area than large farms; second, the attitude of small farmers, who accordingly care more about resource-efficiency and are generally more motivated and committed.

The first argument is related to the fact that small farms are less mechanized because their operators usually have low spending power. This means that a lack of financial resources makes these farms environmentally more sustainable. If we do not want to idealise poverty as the solution for sustainability, it must be said that (1) mechanization per se is not unsustainable and perfectly compatible with agroecological management [79] and (2) that it is at least likely that small farmers would use more tractors (and fuel) if they had the money to purchase them. That biodiverse farms, adapted to the local environment, are more resourceefficient than conventional ones, is a matter fact, but again, this is a management question, not a size question. 
Table 3. Explanations of sustainability benefits of small farms $[1,2,4,18,19,23-25,31,34,41,43,45,47,80]$, their direct relation to farm size and to the farmer's management decisions and attitude.

\begin{tabular}{|c|c|c|c|}
\hline Benefit & $\begin{array}{l}\text { Justification (factors independent } \\
\text { from farmer decisions) }\end{array}$ & Relation to farm size & $\begin{array}{l}\text { Factors that depend on farmer } \\
\text { decisions }\end{array}$ \\
\hline \multicolumn{4}{|c|}{ Farm-level } \\
\hline $\begin{array}{l}\text { Use of local and diverse resources } \\
\text { (e.g. crop landraces) }\end{array}$ & $\begin{array}{l}\text { Restricted (physical and financial) } \\
\text { access to synthetic products; } \\
\text { knowledge about traditional farming }\end{array}$ & Limited financial resources & $\begin{array}{l}\text { Risk minimization through } \\
\text { diversification; application of traditional } \\
\text { knowledge }\end{array}$ \\
\hline Efficient resource use & & None / not specified & $\begin{array}{l}\text { Farm management adapted to local } \\
\text { climate and soils; use of on-farm } \\
\text { resources }\end{array}$ \\
\hline $\begin{array}{l}\text { Low dependence on external (off-farm) } \\
\text { inputs }\end{array}$ & & None / not specified & $\begin{array}{l}\text { Functional agrobiodiversity; use of } \\
\text { local (well-adapted) varieties/breeds }\end{array}$ \\
\hline $\begin{array}{l}\text { In-situ conservation of local varieties } \\
\text { and landraces }\end{array}$ & $\begin{array}{l}\text { Restricted (physical and financial) } \\
\text { access to conventional seeds }\end{array}$ & Limited financial resources & $\begin{array}{l}\text { Use of local varieties/breeds; (climate) } \\
\text { risk minimization; knowledge about } \\
\text { traditional farming (seed selection); }\end{array}$ \\
\hline Diversity of cropping systems & $\begin{array}{l}\text { Knowledge about traditional farming; } \\
\text { subsistence farming (diversity is basis } \\
\text { for nutrition and other uses); } \\
\text { integration into local culture }\end{array}$ & None / not specified & Application of traditional knowledge \\
\hline $\begin{array}{l}\text { Supply of stable yields. elevated } \\
\text { productivity per plant }\end{array}$ & & None / not specified & $\begin{array}{l}\text { Functional agrobiodiversity; active } \\
\text { soils; farm management adapted to } \\
\text { local climate and soils }\end{array}$ \\
\hline Low use of fossil fuels & $\begin{array}{l}\text { Restricted (physical and financial) } \\
\text { access to arm vehicles; no need (due } \\
\text { to farm size); decreased potential for } \\
\text { mechanization; frequently availability } \\
\text { of family labour }\end{array}$ & $\begin{array}{l}\text { Mechanized small farms require less } \\
\text { fuel per area by trend than large farms; } \\
\text { limited financial resources }\end{array}$ & None \\
\hline $\begin{array}{l}\text { Adaptation to changing environmental } \\
\text { conditions and minimization of risk of } \\
\text { harvest loss }\end{array}$ & & None / not specified & $\begin{array}{l}\text { Adaptation to local environment; } \\
\text { functional agrobiodiversity }\end{array}$ \\
\hline \multicolumn{4}{|c|}{ Farmer (family) personal and economic level } \\
\hline $\begin{array}{l}\text { Provision with diverse and healthy } \\
\text { food }\end{array}$ & $\begin{array}{l}\text { Agrobiodiversity and cropping system } \\
\text { diversity; dependence on nutritional } \\
\text { diversity (subsistent farming) }\end{array}$ & Limited financial resources & $\begin{array}{l}\text { Agrobiodiversity and cropping system } \\
\text { diversity }\end{array}$ \\
\hline High sense of responsibility & & Limited financial resources & $\begin{array}{l}\text { Constant observation of the } \\
\text { environment; integration into local } \\
\text { culture; advanced innovation skills }\end{array}$ \\
\hline Sense of purpose and control & $\begin{array}{l}\text { Independence from multinational } \\
\text { corporations; independence from } \\
\text { markets and politics; }\end{array}$ & None / not specified & Integration into local culture \\
\hline Identification of supply niches & & None / not specified & $\begin{array}{l}\text { Innovative skills; observation of the } \\
\text { environment }\end{array}$ \\
\hline Diversification of farm-income & & None / not specified & $\begin{array}{l}\text { Agrobiodiversity provides wide array of } \\
\text { farm products; possibilities for } \\
\text { ecotourism }\end{array}$ \\
\hline \multicolumn{4}{|c|}{ Community level } \\
\hline $\begin{array}{l}\text { Maintenance of local culture and } \\
\text { traditions }\end{array}$ & Knowledge about traditional farming & None / not specified & Integration into local culture \\
\hline Maintenance of social fabric & High labour demand & Limited financial resources & Consumption of local products \\
\hline Prevention of migration to urban areas & High labour demand & None / not specified & Integration into local culture \\
\hline $\begin{array}{l}\text { Support of local (farm and non-farm) } \\
\text { employment }\end{array}$ & Dependence on local infrastructure & None / not specified & \\
\hline Stimulation of local businesses & Limited transport opportunities & Limited transport opportunities & Use of local and on-farm resources \\
\hline $\begin{array}{l}\text { Ecosystem services to surrounding } \\
\text { areas }\end{array}$ & & None / not specified & Functional agrobiodiversity \\
\hline Diversity of landscapes & & None / not specified & $\begin{array}{l}\text { Functional agrobiodiversity; diversity } \\
\text { of uses of the farming system }\end{array}$ \\
\hline
\end{tabular}


Thus, remains the attitude-argument. Although explicit studies comparing the attitude of large and small farmers were not identified, for everybody who has worked with farmer communities in both developed and developing countries, this seems to be the most plausible argument: small farmers opt for a more sustainable farm management not only because they economically depend on their sustainability (due to a lack of money for off-farm inputs) but also because they are more committed to their environment and their community. Yet, is it the farm size that makes them think this way? Couldn't it just as well be their socio-cultural background? And, is it unimaginable that these farmers could operate a larger farm with the same attitude? Studies that explore a potential critical farm size (that may affect the sustainability of a farm due to changing farmer decisions) would be helpful in this regard.

The small farms are more sustainable just because they are small claim needs to be reconsidered. The improper idealization of small farms distracts from an effectively meaningful academic discussion about the role of farm size on shaping and constraining sustainable practices at the farm level and in the broader food system.

It is highly probable that most authors treated in this review are aware that what makes small farms more sustainable is their management, not their size. So, is it only pedantry to insist on a more accurate use of the term small farm?

The present review suggests that it does make sense to call it traditional, peasant-style, agrobiodiverse, or agroecological farm management (instead of just small farm) if it is this what somebody wants to say. This would avoid potential misunderstandings among students, scholars, community activists, non-government organizations, decision-makers, and the farmers themselves. Additionally, the misleading use of the term small farm has concrete policy implications as it suggests that large farms are a priori less sustainable and should, therefore, be disintegrated. Thus, wouldn't it be more essential for a large farm to learn from a small farm rather than to become one? Since the farmer's attitude to farm management seems to be the crucial factor in the whole discussion (and this attitude is shaped by the SES a farm belongs to), creating conditions so that a large farm could be successfully operated like a biodiverse small farm is a complex mission for politics and education. Abandoning the idealization of small farms in agroecology would also foster discussions about how peasant farms could become economically more sustainable and less hard to operate. This is not a claim for growth in terms of area but for decreasing competition among smallholders, for example through farmer cooperatives and collective bargaining.

What most agroecologists agree on is that in order to meaningfully increase the sustainability of the global food system, more food must be produced agroecologically. Whether this can be achieved through more smallholder farms, more sustainable larger farms, or a mixture of both strategies (dependent on the region), and how this can be accomplished, are the essential questions in this regard $[22,43]$. Misleading use of the term small farm in not helpful but only inhibits sustainable development within the food system.

\section{Acknowledgments}

I am grateful to Alexandra Thornton and Alyssa Stewart for their assistance with the review of my manuscript, which improved it significantly.

\section{References and Notes}

[1] Parmentier S. Scaling-up Agro Ecological Approaches: What, Why and How. Oxfam-Solidarity, Brussels. 2014;pp. 472-480. Available from: http://www.fao.org/fileadmin/ templates/agphome/scpi/Agroecology/Agroecology_Scalingup_agroecology_what_why_and_how_-OxfamSol-FINAL.pdf.

[2] van der Ploeg JD. The Importance of Peasant Agriculture: A Neglected Truth; 2016. 10.18174/403213.

[3] Giraldo OF, Rosset PM. Agroecology as a Territory in Dispute: Between Institutionality and Social Movements. The Journal of Peasant Studies. 2017;45(3):545-564. doi:10.1080/03066150.2017.1353496.

[4] Nicholls Cl, Altieri MA. Pathways for the Amplification of Agroecology. Agroecology and Sustainable Food Systems. 2018;42(10):11701193. doi:10.1080/21683565.2018.1499578.

[5] González de Molina Navarro M. Agroecology and Politics: On the Importance of Public Policies in Europe. In: Law and Agroecology. Springer Berlin Heidelberg; 2015. pp. 395-410. doi:10.1007/978-3662-46617-9_20.

[6] Wezel A, Bellon S, Doré T, Francis C, D V, David C. Agroecology as a Science, a Movement and a Practice. In: Sustainable Agriculture. vol. 2. Springer Netherlands; 2011. pp. 27-43. doi:10.1007/978-94007-0394-0_3.

[7] Valenzuela H. Agroecology: A Global Paradigm to Challenge Mainstream Industrial Agriculture. Horticulturae. 2016;2(1):2.

doi:10.3390/horticulturae2010002.

[8] Anderson CR, Bruil J, Jahi Chappell M, Kiss C, Pimbert MP. From Transition to Domains of Transformation: Getting to Sustainable and Just Food Systems through Agroecology. Sustainability. 2019 sep;11(5272). doi:10.3390/su11195272.

[9] Mockshell J, Kamanda J. Beyond the Agroecological and Sustainable Agricultural Intensification Debate: Is Blended Sustainability the Way Forward? International Journal of Agricultural Sustainability. 2018;16(2):127-149. doi:10.1080/14735903.2018.1448047.

[10] Lowder SK, Skoet J, Raney T. The Number, Size, and Distribution of Farms, Smallholder Farms, and Family Farms Worldwide. World Development. 2016;87:16-29. doi:10.1016/j.worlddev.2015.10.041.

[11] Braun V, Clarke V. Using Thematic Analysis in Psychology. Qualitative Research in Psychology. 2006;3(2):77-101. doi:10.1191/1478088706qp063oa.

[12] Rapsomanikis G. Small Farms Big Picture: Smallholder agriculture and structural transformation. Development. 2015;58(2-3):242-255. doi:10.1057/s41301-016-0028-y.

[13] Herrero M, Thornton PK, Power B, Bogard JR, Remans R, Fritz S, et al. Farming and the Geography of Nutrient Production for Human Use: A Transdisciplinary Analysis. The Lancet Planetary Health. 2017;1(1):e33-e42. doi:10.1016/s2542-5196(17)30007-4.

[14] Graeub BE, Chappell MJ, Wittman H, Ledermann S, Bezner Kerr R, Gemmill-Herren B. The State of Family Farms in the World. World Development. 2016;87:1-15. doi:10.1016/j.worlddev.2015.05.012. 
[15] Investing in Smallholder Agriculture for Food Security: A Report by the High Level Panel of Experts on Food Security and Nutrition; 2013.

[16] McGuire S. FAO, IFAD, and WFP. The State of Food Insecurity in the World 2015: Meeting the 2015 International Hunger Targets: Taking Stock of Uneven Progress. Rome: FAO, 2015. Advances in Nutrition. 2015;6(5):623-624. doi:10.3945/an.115.009936.

[17] Córdova R, Hogarth N, Kanninen M. Sustainability of Smallholder Livelihoods in the Ecuadorian Highlands: A Comparison of Agroforestry and Conventional Agriculture Systems in the Indigenous Territory of Kayambi People. Land. 2018;7(2):45. doi:10.3390/land7020045.

[18] Garner E, de la O C, Paula A. Identifying the Family Farm. An Informal Discussion of the Concepts and Definitions. ESA Working Paper. 2014;10(14):2-37. Available from: http://www.fao.org/economic/esa.

[19] Ikers J. Small Farms are Real Farms; 2008.

[20] Rosset P. Food Sovereignty and Alternative Paradigms to Confront Land Grabbing and the Food and Climate Crises. Development. 2011;54(1):21-30. doi:10.1057/dev.2010.102.

[21] Ricciardi V, Ramankutty N, Mehrabi Z, Jarvis L, Chookolingo B. How much of the World's Food Do Smallholders Produce? Global Food Security. 2018;17:64-72. doi:10.1016/j.gfs.2018.05.002.

[22] Ferguson BG, Aldasoro MM, Giraldo O, Mier M, Giménez Cacho $\mathrm{T}$, Morales $\mathrm{H}$, et al. Special Issue Editorial: What Do We Mean by Agroecological Scaling? Agroecology and Sustainable Food Systems. 2019;43(7-8):722-723. doi:10.1080/21683565.2019.1630908.

[23] Berti G, Mulligan C. Competitiveness of Small Farms and Innovative Food Supply Chains: The Role of Food Hubs in Creating Sustainable Regional and Local Food Systems. Sustainability. 2016;8(7):616. doi:10.3390/su8070616.

[24] Altieri MA. Agroecology, Small Farms, and Food Sovereignty. Monthly Review. 2009;61(3):102. doi:10.14452/mr-061-03-2009-07_8.

[25] Astier M, García-Barrios L, Galván-Miyoshi Y, González-Esquivel $\mathrm{CE}$, Masera OR. Assessing the Sustainability of Small Farmer Natural Resource Management Systems. A Critical Analysis of the MESMIS Program (1995-2010). Ecology and Society. 2012;17(3). doi:10.5751/es-04910-170325.

[26] von Loeper WJ, Drimie S, Blignaut J. The Struggles of Smallholder Farmers: A Cause of Modern Agricultural Value Chains in South Africa. In: Agricultural Value Chain. InTech; 2018. doi:10.5772/intechopen.75710.

[27] Frison E. From Industrial Agriculture to Diversified Agroecological Systems. Indian Journal of Plant Genetic Resources. 2016;29(3):237. doi:10.5958/0976-1926.2016.00033.4.

[28] Shiferaw BA, Okello J, Reddy RV. Adoption and Adaptation of Natural Resource Management Innovations in Smallholder Agriculture: Reflections on Key Lessons and Best Practices. Environment, Development and Sustainability. 2007;11(3):601-619. doi:10.1007/s10668007-9132-1.

[29] Arnés E, Antonio J, del Val E, Astier M. Sustainability and Climate Variability in Low-input Peasant Maize Systems in the Central Mexican Highlands. Agriculture, Ecosystems \& Environment. 2013;181:195-205. doi:10.1016/j.agee.2013.09.022.

[30] Smallholders and Family Farmers. Sustainability Pathways; 2012.

[31] Hazell P, Poulton C, Wiggins S, Dorward A. The Future of Small Farms: Trajectories and Policy Priorities. World Development. 2010;38(10):1349-1361. doi:10.1016/j.worlddev.2009.06.012.

[32] for Agricultural Development IF. Investing in Smallholder Family Agriculture for Global Food Security and Nutrition. IFAD Post-2015 Policy Brief 3. 2015;pp. 1-8. Available from: https://www.ifad.org/documents/38714170/39135645/IFAD+Policy+ brief+3+-++lnvesting+in+smallholder+family+agriculture+for+ global+food+security+and+nutrition.pdf/f81a75f1-854f-4b79-b569d5b8566ca2fe.

[33] Adamopoulos T, Restuccia D. The Size Distribution of Farms and International Productivity Differences. American Economic Review. 2014;104(6):1667-1697. doi:10.1257/aer.104.6.1667.

[34] Altieri MA, Nicholls Cl. Agroecology Scaling Up for Food Sovereignty and Resiliency. In: Sustainable Agriculture Reviews. Springer Netherlands; 2012. pp. 1-29. doi:10.1007/978-94-007-5449-2_1.

[35] Ebel R, Mendez-Aguilar M, Putnam H. One Sister Got Climatesick. The Impact of Climate Change on Traditional Maya Farming Systems. International Journal of Sociology of Agriculture \& Food.
2018;24(2):175-199.

[36] Batterbury S. The Context for Smallholder Farming is a Political Ecology of Agrarian Change. N8 AgriFood 2017 International Sustainable Food Production Conference; 2017.

[37] Harvey CA, Saborio-Rodríguez M, M Martinez-Rodríguez R, Viguera B, Chain-Guadarrama A, Vignola R, et al. Climate Change Impacts and Adaptation among Smallholder Farmers in Central America. Agriculture \& Food Security. 2018;7(1). doi:10.1186/s40066-018-0209-x.

[38] Navarro LM, Pereira HM. Rewilding Abandoned Landscapes in Europe. In: Rewilding European Landscapes. Springer International Publishing; 2015. pp. 3-23. doi:10.1007/978-3-319-12039-3_1.

[39] Nelson PB, Oberg A, Nelson L. Rural Gentrification and Linked Migration in the United States. Journal of Rural Studies. 2010;26(4):343352. doi:10.1016/j.jrurstud.2010.06.003.

[40] Glasbergen P. Smallholders do not Eat Certificates. Ecological Economics. 2018;147:243-252. doi:10.1016/j.ecolecon.2018.01.023.

[41] Zimmerer KS, Carney JA, Vanek SJ. Sustainable Smallholder Intensification in Global Change? Pivotal Spatial Interactions, Gendered Livelihoods, and Agrobiodiversity. Current Opinion in Environmental Sustainability. 2015;14:49-60. doi:10.1016/j.cosust.2015.03.004.

[42] Ebel R, Castillo-Cocom JA. From Traditional to "Modern" Farming in a Maya Community. 2012;Available from: https://www.researchgate. net/publication/277712331.

[43] Amekawa Y. Agroecology and Sustainable Livelihoods: Towards an Integrated Approach to Rural Development. Journal of Sustainable Agriculture. 2011;35(2):118-162. doi:10.1080/10440046.2011.539124.

[44] Wibbelmann M, Schmutz U, Wright J, Udall D, Rayns F, Kneafsey M, et al. Mainstreaming Agroecology: Implications for Global Food and Farming Systems; 2013.

[45] Holt-Giménez E, Altieri MA. Agroecology, Food Sovereignty and the New Green Revolution. Journal of Sustainable Agriculture. 2012;pp. 90-102. doi:10.1080/10440046.2012.716388.

[46] Altieri MA, Funes-Monzote FR, Petersen P. Agroecologically Efficient Agricultural Systems for Smallholder Farmers: Contributions to Food Sovereignty. Agronomy for Sustainable Development. 2011;32(1):113. doi:10.1007/s13593-011-0065-6.

[47] Wiggins S. Can the Smallholder Model Deliver Poverty Reduction and Food Security; 2009.

[48] Altieri M, Nicholls Cl. Agroecology and the Search for a Truly Sustainable Agriculture. Basic Textbooks for Environmental Training 9. United Nations Environmental Program, Environmental Training Network for Latin America and the Caribbean; 2005.

[49] Lin BB. Resilience in Agriculture through Crop Diversification: Adaptive Management for Environmental Change. BioScience. 2011;61(3):183-193. doi:10.1525/bio.2011.61.3.4.

[50] Rosset P. The Multiple Functions and Benefits of Small Farm Agriculture in the Context of Global Trade Negotiations. Development. 2000;43(2):77-82. doi:10.1057/palgrave.development.1110149.

[51] Francis CA. Advances in the Design of Resource-Efficient Cropping Systems. Journal of Crop Production. 2003;8(1-2):15-32. doi:10.1300/j144v08n01_02.

[52] Gliessman SR. Agroecology. CRC Press; 2006. doi:10.1201/b17420.

[53] Hazell P, Poulton C, Wiggins S, Dorward A. Comportamiento de Tres Especies (Maíz, Frijol, Calabaza) en Policultivos en la Chontalpa, Tabasco, México. Colegio Superior de Agricultura Tropical; 1980.

[54] Gliessman S. Multiple Cropping Systems: A Basis for Developing an Alternative Agriculture. In: Innovative Biological Technologies for Lesser Developed Countries: Workshop Proceedings. Congress of the USA; 1985. pp. 67-83.

[55] Gliessman S. Agroecology: Ecological Processes in Sustainable Agriculture. vol. 2. Ann Arbor Press; 1998.

[56] Dorward A. Farm Size and Productivity in Malawian Smallholder Agriculture. Journal of Development Studies. 1999;35(5):141-161. doi:10.1080/00220389908422595.

[57] Funes-Monzote FR, Monzote M, Lantinga EA, Ter Braak CJF, Sánchez JE, Van Keulen H. Agro-Ecological Indicators (AEIs) for Dairy and Mixed Farming Systems Classification: Identifying Alternatives for the Cuban Livestock Sector. Journal of Sustainable Agriculture. 2009;33(4):435-460. doi:10.1080/10440040902835118.

[58] Funes-Monzote FR, Martín GJ, Suárez J, Blanco D, Reyes F, Cepero $\mathrm{L}$, et al. Evaluacion inicial de sistemas integrados para la produccion 
de alimentos y energia en Cuba. Pastos y Forrajes. 2011;34(4):445462.

[59] Holt-Giménez E. Measuring Farmers' Agroecological Resistance After Hurricane Mitch in Nicaragua: A Case Study in Participatory, Sustainable Land Management Impact Monitoring. Agriculture, Ecosystems \& Environment. 2002;93(1-3):87-105. doi:10.1016/s01678809(02)00006-3.

[60] Lin BB. Agroforestry Management as an Adaptive Strategy Against Potential Microclimate Extremes in Coffee Agriculture. Agricultural and Forest Meteorology. 2007;144(1-2):85-94. doi:10.1016/j.agrformet.2006.12.009.

[61] Natarajan M, Willey RW. The Effects of Water Stress on Yield Advantages of Intercropping Systems. Field Crops Research. 1986;13:117131. doi:10.1016/0378-4290(86)90015-8.

[62] Isakson SR. No Hay Ganancia en la Milpa: The Agrarian Question, Food Sovereignty, and the On-farm Conservation of Agrobiodiversity in the Guatemalan Highlands. The Journal of Peasant Studies. 2009;36(4):725-759. doi:10.1080/03066150903353876.

[63] Altieri MA. Applying Agroecology to Enhance the Productivity of Peasant Farming Systems in Latin America. Environment, Development and Sustainability. 1999;1(3/4):197-217. doi:10.1023/a:1010078923050.

[64] Nicholls Cl, Altieri M. Modelos Ecológicos y Resilientes de Producción Agrícola para el siglo XXI. Agroecología. 2011;6(1):28-37.

[65] Emerson PM, Vertrees JG, Goldschmidt W, Drache HM. As You Sow: Three Studies in the Social Consequences of Agribusiness. American Journal of Agricultural Economics. 1979;61(4):712. doi:10.2307/1239924

[66] Koohafkan P. Globally Important Agricultural Heritage Systems (GIAHS): A Legacy for Food and Nutrition Security. In: Sustainable Diets: Linking Nutrition and Food Systems. CABI; 2019. pp. 204-214. doi:10.1079/9781786392848.0204.

[67] Agrawal A. Dismantling the Divide Between Indigenous and Scientific Knowledge. Development and Change. 1995;26(3):413-439. doi:10.1111/j.1467-7660.1995.tb00560.x

[68] Gliessman S. Saving Seeds and Saving Culture. Agroecology and Sustainable Food Systems. 2015;39(6):599-600. doi:10.1080/21683565.2015.1025894

[69] Gliessman S. Transforming Food Systems to Sustainability with Agroecology. Journal of Sustainable Agriculture. 2011;35(8):823825. doi:10.1080/10440046.2011.611585.

[70] Wezel A, Casagrande M, Celette F, Vian JF, Ferrer A, Peigné J. Agroecological Practices for Sustainable Agriculture. A Review. Agronomy for Sustainable Development. 2013;34(1):1-20. doi:10.1007/s13593013-0180-7.

[71] Steinfeld H, Wassenaar T, Jutzi S. Livestock Production Systems in Developing Countries: Status, Drivers, Trends. Revue scientifique et Technique. 2006;25(2):505-516. doi:10.20506/rst.25.2.1677.

[72] Pretty J. Agricultural Sustainability: Concepts, Principles and Evidence. Philosophical Transactions of the Royal Society B: Biological Sciences. 2007;363(1491):447-465. doi:10.1098/rstb.2007.2163.

[73] Gliessman SR, editor. Agroecosystem Sustainability. CRC Press; 2000. doi:10.1201/9781420041514.

[74] Zahm F, Viaux P, Vilain L, Girardin P, Mouchet C. Assessing Farm Sustainability with the IDEA Method - from the Concept of Agriculture Sustainability to Case studies on Farms. Sustainable Development. 2008;16(4):271-281. doi:10.1002/sd.380.

[75] Glaser M, Krause G, Ratter B, Welp M. Human/Nature Interaction in the Anthropocene Potential of Social-Ecological Systems Analysis. GAIA - Ecological Perspectives for Science and Society. 2008;17(1):77-80. doi:10.14512/gaia.17.1.18.

[76] Ostrom E. A General Framework for Analyzing Sustainability of Social-Ecological Systems. Science. 2009;325(5939):419-422. doi:10.1126/science.1172133.

[77] Seghezzo L. The Five Dimensions of Sustainability. Environmenal Politics. 2009;18(4):539-556. doi:10.1080/09644010903063669.

[78] Levins R. Science and Progress: Seven Developmentalist Myths in Agriculture. Monthly Review. 1986;38(3):13. doi:10.14452/mr-03803-1986-07_3.

[79] De Schutter O. Agroecology, a Tool for the Realization of the Right to Food. In: Agroecology and Strategies for Climate Change. Springer Netherlands; 2011. pp. 1-16. doi:10.1007/978-94-007-1905-7_1.

[80] Sustainable Smallholder Agriculture: Feeding the World, Protecting the Planet. IFAD Governing Council; 2012. 